\title{
Identification of Vietnamese Ochna integerrima (Lour.) Merr Species Based on Ribosomal DNA Internal Transcribed Spacer Sequence
}

\section{Dang Hoang Trang ${ }^{1}$, Dang Van Dong ${ }^{2}$, Bui Huu Chung ${ }^{2}$, Dong Huy Gioi ${ }^{1}$ Tran Dang Khanh ${ }^{3^{*}}$}

\author{
${ }^{1}$ Faculty of Biotechnology, Vietnam National University of Agriculture, Hanoi, Vietnam; \\ ${ }^{2}$ Centre for Flower and Ornamental Research and Development, Institute of Fruit and Vegetable, \\ Hanoi Vietnam; \\ ${ }^{3}$ Genetic Engineering Department, Agricultural Genetics Institute, Hanoi, Vietnam. \\ khanhkonkuk@gmail.com
}

Keywords: Ochna integerrima, ITS, gene sequence, flower, species

\begin{abstract}
Ochna integerrima is a medicinal and ornamental plant, is widely distributed in Southeast Asia areas. In Vietnam, it has been ranked as the rare and endangered species due to its high demand trade of the beautiful species. In this study, total 21 Ochna samples, collected from the northern and southern areas, were used to characterize the morphological traits using morphological analyses and molecular tool. The results have revealed that the morphological characterization of flower and its quality of Yen Tu Ochna samples showed differences in comparison with the common Ochna and southern Ochna samples. To accurately distinguish genetic traits of the samples, we have sequenced the internal transcribed spacer (ITS) region (including ITS1, 5.8S) of 21 species. The results have disclosed the genetic correlations of the samples ranging from $96.25 \%$ to $100 \%$ among the studied Ochna samples, of which 5 samples include B1, B2, B3, B6 and N3.1 were divided into the separate groups. The current work is the first report in constructing a molecular database of Ochna for further assessment of inter-and intra-specific molecular diversity of Ochna species in Vietnam.
\end{abstract}

\section{Introduction}

The genus Ochna belongs to Ochnaceae of the order Ochnales which was narrated in the first edition of Genera Plantarum [1]. Several species have been commonly used as medicinal and ornamental plants. Ochna is of evergreen trees, shrubs and shrublets and is distributed in tropical Southeastern Asia, Africa and America [2]. According to the report of Hoe [3] O. integerrima consists of two main species based on its typical flower colour included: white and yellow flower. They have approximate 26-35 genera and 495-600 species, depending on the classification system and widely found in the subtropical and tropical areas. The white flower plant belonging to the genus Prunus was derived from China and was then spread to Japan and Korea. It is now grown in cool climate for fruit and flowers [4].

In Vietnam, the yellow flower plant is known as O. integerrima, belonging to Ochnaceae family, which consists of more than 300 species. O. integerrima has characteristics adaptable to warm tropical in South East Asia and Africa. This species is widely developed in areas of the Central of Vietnam (Da Nang province to South). The plant is popularly used as the bonsai species in this country including $O$. integerrima (five petals- mountain flower plant) and $O$. atropurpurea (four seasons flower) [4]. Some members of this genus have been cultivated as the decorative plants because of their colourful flowers and unusual fruits, for instance: O. kirkii, O. mossambicensis, O. schweinfurthiana, O. serrulata and O. thomasiana [5]. O. integerrima species is called in Vietnamese "mickey-mouse plant" or "lucky flower" and is grown as an ornamental garden plant due to its typically beautiful flower. The yellow flowers are often utilized to celebrate the occasion of the Vietnamese Lunar New Year. The species of $O$. integerrima with five petals with yellow flowers are called in Vietnamese "Mai vang" whereas the mountain flowers known as "Mai nui" which have five to nine petals. The size of each plant depends on its age and ecological areas. The 
average height is over $1 \mathrm{~m}$ for 5-year-old-tree. The blight yellow flowers are symbolized for happiness, health and prosperity [6]. This genus is rich in some medicinal compounds such as bioflavonoids, anthranoids and oavonoids [7, 8]. The leaves have long been used in traditional medicine for treatment of various ailments included: asthma, dysentery, epilepsy, gastric disorders, menstrual, lumbago, ulcers, and also used as an abortifacient, or antidote against snakebite [5]. The plant bark and roots are often used in traditional medicine as a digestive tonic and a cathartic for worms and a medicine for lymphatic disorder [6].

In northern of Vietnam, O. integerrima plant was discovered in a long time ago at Yen $\mathrm{Tu}$ mountainous areas. Due to its typical colourful flower, this plant has been paid much attention to be adopted for decoration. According to the historical documents, the yellow flowers plant was called "golden age" which derived from over 800 years ago (1285-1288 generation). However, the questions have emerged that whether Yen Tu Ochna and the southern Ochna are the same or different species. Some reports have stated that that Yen Tu Ochna and the southern plant may derive from the same origin. Some views have debated that they are different species [9].

In Vietnam, there are currently sporadical studies on O. integerrima species. Some initial reports focused only on conservation, storage and classification at geographic level of its distribution [9]. Many of O. integerrima species are complicated to separate without their flowers and phenotypic characteristics. Traditionally, the Vietnamese botanists have identified and classified the relationship of Ochna species depending on its habitats, morphological and cytological characteristics. However, these methods are curbed by the adverse impacts of climate change and diagnostic resolution.

Recently, molecular markers have been widely applied to distinguish the related plants and shown to be feasible methods. The internal transcribed spacer (ITS) is one of the most extensively applied molecular markers for angiosperm. Therefore, the objectives of the current study were to characterize the morphological traits of 21 Ochna species as well as investigate genetic variability and relationships among the studied species by sequencing the internal transcribed spacer (ITS) region.

\section{Materials and Methods}

\section{Plant materials}

A total of $21 O$. integerrima varieties were kindly provided by the Fruit and Vegetable Research Institute in 2016. They were collected from some different areas in both northern and southern areas of Vietnam. The native name and origin as well as collected areas are shown in the Table 1. 
Table 1. List of the varieties used in analyses in this study.

\begin{tabular}{|l|l|c|l|l|}
\hline No & \multicolumn{1}{|c|}{ Native name } & Code & \multicolumn{1}{c|}{ Origin/province } & \multicolumn{1}{c|}{ Collected area } \\
\hline 1 & Mai YenTu 1 & B1 & Yen Tu (Quang Ninh) & Gia Lam (Hanoi) \\
\hline 2 & Mai YenTu 2 & B2 & Yen Tu (Quang Ninh) & Gia Lam (Hanoi) \\
\hline 3 & Mai YenTu 3 & B3 & Yen Tu (Quang Ninh) & Gia Lam (Hanoi) \\
\hline 4 & Mai Hue & B4 & Hue & Gia Lam (Hanoi) \\
\hline 5 & Mai vang & B5 & Hanoi & Gia Lam (Hanoi) \\
\hline 6 & Mai YenTu 4 & B6 & Yen Tu (Quang Ninh) & Quang Ninh \\
\hline 7 & Mai xoan & B7 & Hanoi & Gia Lam (Hanoi) \\
\hline 8 & Cucmai1 & N1.1 & Southern of Vietnam & Binh Dinh \\
\hline 9 & Cucmai2 & N1.2 & Southern of Vietnam & Binh Dinh \\
\hline 10 & Cucmai3 & N1.3 & Southern of Vietnam & Binh Dinh \\
\hline 11 & Cuc mai Thuong Hai & N1.5 & China & Binh Dinh \\
\hline 12 & Mai giao1 & N2.1 & Southern of Vietnam & Binh Dinh \\
\hline 13 & Mai giao2 & N2.2 & Southern of Vietnam & Binh Dinh \\
\hline 14 & Mai giao3 & N2.3 & Southern of Vietnam & Binh Dinh \\
\hline 15 & Hong mai & N2.4 & Southern of Vietnam & Binh Dinh \\
\hline 16 & Mai giao4 & N2.5 & Southern of Vietnam & Binh Dinh \\
\hline 17 & Mai huong 5 canh & N3.1 & Southern of Vietnam & Binh Dinh \\
\hline 18 & Mai vang 5 canh & N3.2 & Southern of Vietnam & Binh Dinh \\
\hline 19 & Mai rung 5 canh & N3.3 & Southern of Vietnam & Binh Dinh \\
\hline 20 & Mai Singapore & N4 & Southern of Vietnam & Binh Dinh \\
\hline 21 & Mai dai doa & N5 & Southern of Vietnam & Binh Dinh \\
\hline
\end{tabular}

Morphological analysis

Morphological traits, both qualitative and quantitative ones, were observed on flowers (collected in March, when the flowers are fully developed) and leaves (collected in March for young leaves and in July for mature leaves).

Qualitative traits include the shape of petals and sepals, aestivation of corolla (involving number of sepals and petals), flower fragrance, colour of young leaves, colour of mature leaves, and leaf shape. These characters were described based on the standard quantitative comparison of phenotypes and expression patterns of flowering plants, particularly Ochnacea family [10,11].

Quantitative traits include corolla diameter and flower longevity (the number of days from blooming to falling off), which were measured with 3-time replication on 5 random individuals of each variety. The results were statistically recorded with ANOVA and t-test by MS EXCEL 2013.

\section{DNA isolation, PCR and sequencing}

Genomic DNA was isolated from leaves of all samples using the CTAB method [12] with some minor modifications. The yielded DNA products were then recorded by using a spectrophotometer [13].

Amplifications were carried out in $15 \mu 1$ volumes with $0.5 \mathrm{U}$ of MyTaq DNA polymerase (Promega, Madison, WI), $2.5 \mathrm{mM} \mathrm{MgCl} 2,1 \mathrm{mM}$ of dNTPs, $1 \mu \mathrm{M}$ of each primer, and undetermined quantities of genomic DNA template in a Mastercycler S. The pair of primers ITS1/ITS8 were used with nucleotide sequence: GGAAGGAGAAGTCGTAACAAGG/ CACGCTTCTCCAGACTACA [14]. After initial denaturation $\left(5 \mathrm{~min}\right.$ at $\left.94^{\circ} \mathrm{C}\right)$, polymerase chain reaction $(\mathrm{PCR})$ was performed for 35 cycles of denaturation $\left(45 \mathrm{~s}\right.$ at $\left.94^{\circ} \mathrm{C}\right)$, primer annealing $\left(45 \mathrm{~s}\right.$ at $\left.59^{\circ} \mathrm{C}\right)$, and primer extension $\left(55 \mathrm{~s}\right.$ at $\left.72^{\circ} \mathrm{C}\right)$. The reactions ended with an elongation period of $4 \mathrm{~min}$ at $72^{\circ} \mathrm{C}$.

PCR products were electrophoresed on 1\% agarose gels in Tris-borate-EDTA buffer and stained with ethidium bromide. Afterwards, amplified double-stranded DNA fragments (750bp) were purified using the "Wizard" DNA cleanup system (Promega, Madison, WI) and directly sequenced on an ABI 373A automated sequencer using the standard dye-terminator chemistry following to manufacture's protocol (Applied Biosystems Inc.). 


\section{Sequence analyses}

The purified PCR products were directly sequenced by an ABI PRISM ${ }^{\mathrm{TM}} 310$ Genetic Analyzer (Applied Biosystem). The primers ITS1 and ITS8 were used for the sequence reaction. The ITS region of each individual was then sequenced in both 5' and 3' directions at least twice to avoid mutation introduced by Taq polymerase. The boundaries of the ITS1 and ITS 8 were determined by comparing them with the published sequences based on the similarity sequence on the NCBI.

\section{Statistical Analysis}

The sequences were aligned and analyzed using the MEGA v5.1 program to generate the phylogeny.

\section{Results and Discussion}

\section{Morphological characterizations}

The total 21 samples of Ochna species were collected in some areas from Vietnam and divided into two main groups: samples from the northern region and samples from the southern region, of which the samples from the northern region were included in two sub-groups: Yen Tu Ochna and common Ochna. In this study, the flower morphology and their quality were evaluated based on the flower diameter, number of sepals, number of petals, shape of petals and sepals, aestivation of corolla, fragrance, flower longevity and duration of flower season (Table 2).

As the observation, the samples reveals variable in diameter of flowers, of which $\mathrm{Yen} \mathrm{Tu}$ and common Ochna showed negligible different of the flower size from 3.4 to $3.7 \mathrm{~cm}$, respectively. Among them, B1 and B2 samples disclosed the highest by $3.7 \mathrm{~cm}$, while B5 and B7 were $3.6 \mathrm{~cm}$, respectively. Contrarily, the samples collected from southern regions exhibited to be higher than that both samples of Yen Tu and common Ochna. The samples N5 showed the highest by $7.2 \mathrm{~cm}$, followed by $\mathrm{N} 4(5.4 \mathrm{~cm})$. Also, 7 samples N1.1, N1.2, N1.3, N1.5, and N2.4 were $4.5 \mathrm{~cm}$. The number of sepals of all samples was 5 sepals except the samples N2.3 (Table 2). It notes that the number of petals of the samples collected from southern region was shown significantly higher than both of Yen Tu and common Ochna. Specifically, 9 Ochna samples included N1.1, N1.2, N1.3, $\mathrm{N} 1.5, \mathrm{~N} 2.1, \mathrm{~N} 2.2, \mathrm{~N} 2.3, \mathrm{~N} 2.5$ and N5 were ranged from 9 to 48 petals, respectively (Table 2).
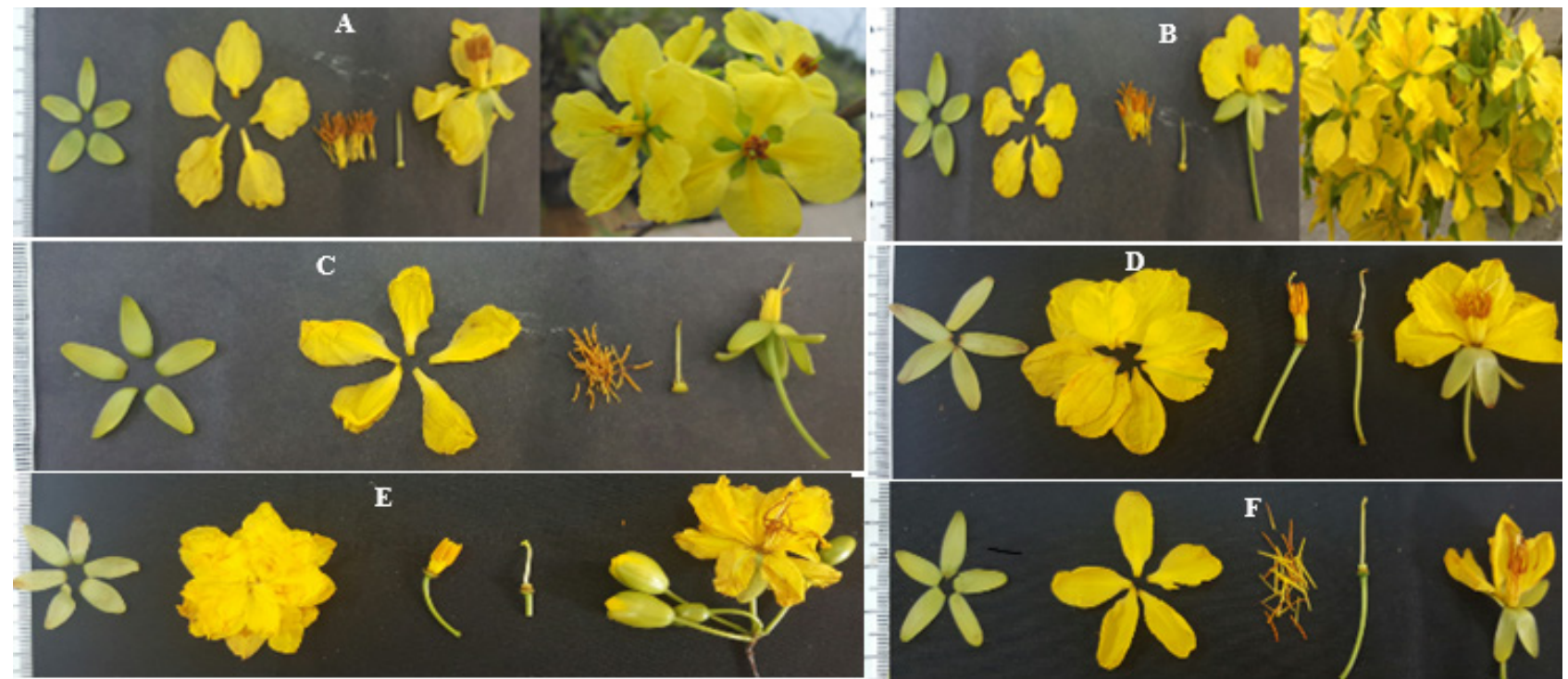

Figure 1. Morphological characteristics of flower samples; A: B1; B: B2; C: B4; D: N2.2; E: N2.3; F: N3.1.

It was monitored that there were only 2 kinds of round and oval shapes of petals and sepals in both samples from northern and southern regions. For the aestivation of the corolla, all samples of northern region were demonstrated the aestivation only, while 9 samples collected from southern 
region were revealed the imbrication with the exception of the 4 samples showed the valvation including N2.4, N3.1, N3.2, N3.3 and N4. It was worthily to mention that Yen Tu Ochna samples have had the fragrance, which contradicted the samples of common Ochna and the samples from the southern region, not including the sample N3.1 (Table 2). To further evaluate the flower longevity and duration of flower season between the Ochna samples from northern and southern regions, the results have shown that the flower of Ochna samples of Yen Tu demonstrated the most longevity by 5.4 to 6.2 days, followed by southern Ochna and the lowest samples were found in the common Ochna. Similarly, the duration of flower season of the samples of Yen Tu Ochna was shown to be highest by 4 to 5 weeks, followed by the southern Ochna which displayed wide range duration of flower season by 3.2 to 4.5 weeks, and the lowest duration was observed in the common Ochna (Table 2).

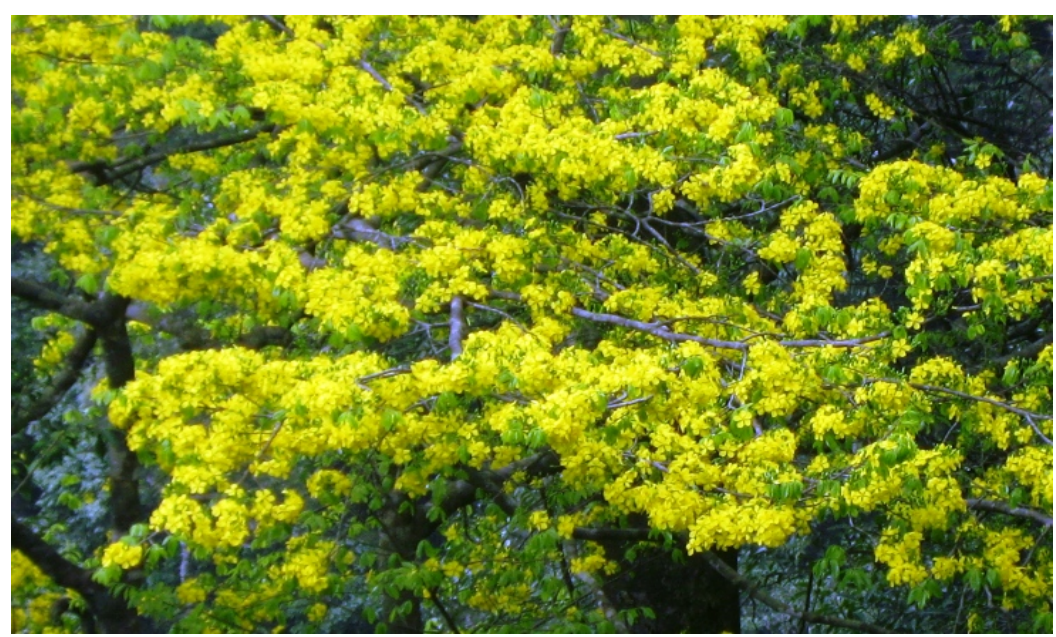

Figure 2. Panorama of Yen Tu Ochna trees in nature [14].

For characterization of leaf morphology amongst the samples, the colors of young leaves of Yen Tu and common Ochna were remarkably different by two major colour of light green and light red. It notes that the samples from southern region exhibited the intense green, which was dissimilar with the samples of Yen Tu and common Ochna samples. However, the leaf blade of all samples showed wide variation amongst the sample. For instance, B1, N1.1, N1.3, N2.1, N2.5 and N4 samples disclosed the elliptical shape. The obovate-lanceolate leaf blade was found in B2, B3, B6 and N3.1, while the obovate-oblong of leaf blade was demonstrated in 11 samples of both groups (Table 3). The leaf base and leaf margin of all samples showed the similarity with cuneate and serrate, but the leaf tip was variable among the group with acute and obtuse of the leaf tip, respectively (Figs. 1, 2).

Some studies reported that Yen Tu Ochna was unique with differences from the other Ochna species based on their branch, bark, leaf, fragrance [15]. According to the recent preliminary investigation on the current distribution of Yen Tu Ochna in nature, the results have shown that most Yen Tu Ochna trees have been 60 years old or older with large trunks, the average perimeter reached $40 \mathrm{~cm}$ with 5 to 7 meter plant height. Most plants have widely adapted on the cliffs with 400 to 900 meters above sea level [16].

Generally, the morphological characterization of the Yen Tu Ochna species including flower and leaf morphology, quality showed typical unique differences to compare with both common and southern Ochna samples.

\section{Molecular markers application to identify Ochna species based on ITS region sequences}

By using ITS1/ITS8 primer pairs, the ITS region was successfully amplified by PCR. The product was then checked on agarose gel $(1.5 \%)$. The obtained results were shown to be high quality with the appearance of only one band with size, which ranged approximately $800 \mathrm{bp}$. Our result was agreed with some previous reports who amplified the ITS region of the plant samples $[17,18]$. To emphasize that the obtained bands were clear and correct size, which are enough quality to use for sequencing. 


\section{Sequencing ITS-rDNA of the Ochna samples}

A total 21 PCR products of 21 Ochna samples was sequenced, then analyzed by the software MEGA v6. The results showed that the 4 different colour peaks appeared, which directly correlated with 4 nucleotides and nucleotide sequences of each sample.

ITS analysis showed that the sequence of nucleotides among Ochna samples has been different. In general, the ration of Guanine and Cytosine were greater than those of Adenine and Thymine. In the other hand, the percentage of GC was found higher than the percentage of AT. Specifically, N2.2 sample revealed the highest GC content by $65.7 \%$ ), while TA content was $34.3 \%$, respectively. The average percentage of GC in all 21 samples was reached $65.3 \%$, and their AT component averaged by $43.7 \%$.

Table 2. Morphological characterization of the Flower and quality of the Ochna samples.

\begin{tabular}{|c|c|c|c|c|c|c|c|c|c|c|}
\hline $\mathrm{Gr}$ & & No & Sample & $\begin{array}{l}\text { Diameter } \\
(\mathrm{cm})\end{array}$ & $\begin{array}{l}\text { Number } \\
\text { of sepals }\end{array}$ & $\begin{array}{l}\text { Number } \\
\text { of petals }\end{array}$ & $\begin{array}{l}\text { Shape of } \\
\text { petals and }\end{array}$ & $\begin{array}{l}\text { Aestivation } \\
\text { of corolla }\end{array}$ & Fragrance & $\begin{array}{l}\text { Flower } \\
\text { longevity }\end{array}$ \\
\hline & & 1 & B1 & $3.7^{\mathrm{a}}$ & 5 & 5 & Round & Valvate & Yes & $5.4^{\mathrm{a}}$ \\
\hline & Yen $\mathrm{Tu}$ & 2 & B2 & $3.7^{\mathrm{a}}$ & 5 & 5 & Round & Valvate & Yes & $5.8^{\mathrm{a}}$ \\
\hline Samples & Ochna & 3 & B3 & $3.4^{\mathrm{a}}$ & 5 & 5 & Round & Valvate & Yes & $6.2^{\mathrm{b}}$ \\
\hline from & & 4 & B6 & $3.5^{\mathrm{a}}$ & 5 & 5 & Oval & Valvate & Yes & $5.4^{\mathrm{a}}$ \\
\hline $\begin{array}{l}\text { Northern } \\
\text { reoion }\end{array}$ & & 5 & B4 & $3.5^{\mathrm{a}}$ & 5 & 5 & Round & Valvate & No & $3.1^{\mathrm{c}}$ \\
\hline & Common & 6 & B5 & $3.6^{\mathrm{a}}$ & 5 & 5 & Oval & Valvate & No & $3.5^{\mathrm{c}}$ \\
\hline & & 7 & B7 & $3.6^{\mathrm{a}}$ & 5 & 5 & Round & Valvate & No & $3.1^{\mathrm{c}}$ \\
\hline & & 8 & N1.1 & $4.5^{b}$ & 5 & 24 & Oval & Imbricate & No & $3.9^{\mathrm{d}}$ \\
\hline & & 9 & $\mathrm{~N} 1.2$ & $4.5^{b}$ & 5 & 48 & Round & Imbricate & No & $3.9^{\mathrm{d}}$ \\
\hline & & 10 & $\mathrm{~N} 1.3$ & $4.5^{b}$ & 5 & 48 & Round & Imbricate & No & $4.0^{\mathrm{d}}$ \\
\hline & & 11 & $\mathrm{~N} 1.5$ & $4.5^{b}$ & 5 & 24 & Oval & Imbricate & No & $3.2^{\mathrm{c}}$ \\
\hline & & 12 & $\mathrm{~N} 2.1$ & $3.7^{\mathrm{a}}$ & 5 & 10 & Round & Imbricate & No & $3.8^{\mathrm{e}}$ \\
\hline & & 13 & $\mathrm{~N} 2.2$ & $3.5^{\mathrm{a}}$ & 5 & 9 & Round & Imbricate & No & $3.8^{\mathrm{e}}$ \\
\hline Sampl & s from & 14 & $\mathrm{~N} 2.3$ & $3.7^{\mathrm{a}}$ & 6 & 12 & Round & Imbricate & No & $4.2^{\mathrm{f}}$ \\
\hline Souther & region & 15 & $\mathrm{~N} 2.4$ & $4.4^{b}$ & 5 & 5 & Round & Valvate & No & $4.5^{\mathrm{f}}$ \\
\hline & & 16 & $\mathrm{~N} 2.5$ & $3.6^{\mathrm{a}}$ & 5 & 10 & Round & Imbricate & No & $4.2^{\mathrm{f}}$ \\
\hline & & 17 & N3.1 & $3.2^{\mathrm{c}}$ & 5 & 5 & Round & Valvate & Yes & $3.2^{\mathrm{c}}$ \\
\hline & & 18 & N3.2 & $4.1^{\mathrm{d}}$ & 5 & 5 & Oval & Valvate & No & $3.4^{\mathrm{c}}$ \\
\hline & & 19 & N3.3 & $4.0^{\mathrm{d}}$ & 5 & 5 & Oval & Valvate & No & $3.9^{\mathrm{e}}$ \\
\hline & & 20 & N4 & $5.4^{\mathrm{e}}$ & 5 & 5 & Round & Valvate & No & $3.5^{\mathrm{c}}$ \\
\hline & & 21 & N5 & $7.2^{f}$ & 5 & 10 & Round & Imbricate & No & $3.5^{\mathrm{c}}$ \\
\hline
\end{tabular}

Note: $a, b, c, d, e$ on the same column indicated statistically significant difference of the means with $P<0,05$ 
Table 3. Leaf morphology of the used samples.

\begin{tabular}{|c|c|c|c|c|c|c|c|c|c|}
\hline & & No & Sample & $\begin{array}{c}\text { Colour of } \\
\text { young }\end{array}$ & $\begin{array}{l}\text { Colour of } \\
\text { mature }\end{array}$ & Leaf blade & Leaf base & Leaf tip & $\begin{array}{c}\text { Leaf } \\
\text { margin }\end{array}$ \\
\hline & & 1 & B1 & $\begin{array}{l}\text { Light } \\
\text { green }\end{array}$ & $\begin{array}{l}\text { Intense } \\
\text { green }\end{array}$ & Elliptical & Cuneate & Acute & Serrate \\
\hline & Yen Tu & 2 & B2 & $\begin{array}{l}\text { Light } \\
\text { green }\end{array}$ & $\begin{array}{l}\text { Intense } \\
\text { green }\end{array}$ & $\begin{array}{l}\text { Obovate- } \\
\text { lanceolate }\end{array}$ & Cuneate & Obtuse & Serrate \\
\hline Samples & Ochna & 3 & B3 & $\begin{array}{l}\text { Light } \\
\text { green }\end{array}$ & $\begin{array}{l}\text { Intense } \\
\text { green }\end{array}$ & $\begin{array}{l}\text { Obovate- } \\
\text { lanceolate }\end{array}$ & Cuneate & Obtuse & Serrate \\
\hline $\begin{array}{l}\text { from } \\
\text { Northern }\end{array}$ & & 4 & B6 & $\begin{array}{l}\text { Light } \\
\text { green }\end{array}$ & $\begin{array}{l}\text { Intense } \\
\text { green }\end{array}$ & $\begin{array}{l}\text { Obovate- } \\
\text { lanceolate }\end{array}$ & Cuneate & Obtuse & Serrate \\
\hline & & 5 & B4 & Light red & $\begin{array}{l}\text { Intense } \\
\text { green }\end{array}$ & Obovate-oblong & Cuneate & Acute & Serrate \\
\hline & $\begin{array}{c}\text { Common } \\
\text { Ochna }\end{array}$ & 6 & B5 & Light red & $\begin{array}{l}\text { Intense } \\
\text { green }\end{array}$ & Obovate-oblong & Cuneate & Obtuse & Serrate \\
\hline & & 7 & B7 & Light red & $\begin{array}{l}\text { Intense } \\
\text { green }\end{array}$ & Obovate-oblong & Cuneate & Acute & Serrate \\
\hline & & 8 & N1.1 & Light red & $\begin{array}{l}\text { Intense } \\
\text { green }\end{array}$ & Elliptical & Cuneate & Cuneate & Serrate \\
\hline & & 9 & $\mathrm{~N} 1.2$ & Light red & $\begin{array}{l}\text { Light } \\
\text { green }\end{array}$ & Obovate-oblong & Cuneate & Cuneate & Serrate \\
\hline & & 10 & N1.3 & Light red & $\begin{array}{l}\text { Light } \\
\text { green }\end{array}$ & Elliptical & Cuneate & Cuneate & Serrate \\
\hline & & 11 & $\mathrm{~N} 1.5$ & Light red & $\begin{array}{l}\text { Light } \\
\text { green }\end{array}$ & Obovate-oblong & Cuneate & Cuneate & Serrate \\
\hline & & 12 & $\mathrm{~N} 2.1$ & Light red & $\begin{array}{l}\text { Light } \\
\text { green }\end{array}$ & Elliptical & Cuneate & Cuneate & Serrate \\
\hline & & 13 & $\mathrm{~N} 2.2$ & Light red & $\begin{array}{l}\text { Intense } \\
\text { green }\end{array}$ & Obovate-oblong & Cuneate & Cuneate & Serrate \\
\hline Sampl & from & 14 & $\mathrm{~N} 2.3$ & Light red & $\begin{array}{l}\text { Intense } \\
\text { green }\end{array}$ & Obovate-oblong & Cuneate & Cuneate & Serrate \\
\hline Souther & region & 15 & $\mathrm{~N} 2.4$ & Light red & $\begin{array}{l}\text { Intense } \\
\text { green }\end{array}$ & Obovate-oblong & Cuneate & Cuneate & Serrate \\
\hline & & 16 & $\mathrm{~N} 2.5$ & Light red & $\begin{array}{l}\text { Intense } \\
\text { green }\end{array}$ & Elliptical & Cuneate & Cuneate & Serrate \\
\hline & & 17 & N3.1 & Light red & $\begin{array}{l}\text { Intense } \\
\text { green }\end{array}$ & $\begin{array}{l}\text { Obovate- } \\
\text { lanceolate }\end{array}$ & Cuneate & Obtuse & Serrate \\
\hline & & 18 & $\mathrm{~N} 3.2$ & Light red & $\begin{array}{l}\text { Intense } \\
\text { green }\end{array}$ & Obovate-oblong & Cuneate & Acute & Serrate \\
\hline & & 19 & N3.3 & Light red & $\begin{array}{l}\text { Intense } \\
\text { green }\end{array}$ & Obovate-oblong & Cuneate & Acute & Serrate \\
\hline & & 20 & $\mathrm{~N} 4$ & Light red & $\begin{array}{l}\text { Light } \\
\text { green }\end{array}$ & Elliptical & Cuneate & Acute & Serrate \\
\hline & & 21 & N5 & Light red & $\begin{array}{l}\text { Light } \\
\text { green }\end{array}$ & Obovate-oblong & Cuneate & Obtuse & Serrate \\
\hline
\end{tabular}

\section{Comparison of ITS-rDNA nucleotide sequence of the Ochna samples}

The segments ITS-rDNA nucleotide sequences of the total 21 Ochna samples were identified and compared. Based on the results of analysis of the diversity of the ITS-rDNA sequences and alignment of the sequences by Mega v6.0 and CLCv8.0 software, it has been revealed that the differences between the major sequences were single polymorphisms (SNPs), in which one nucleotide was replaced by another nucleotide. In general, approximately 100 nucleotides changed their position. Specifically, the sequences ranged from 80 to 120 observed the deletion of segments, for example, the B1, B2, B3, B6 and N3.1 samples showed nucleotide sequence 80 to 85 and 108 to 112, respectively (Fig. 3). Moreover, other positions of nucleotide sequence revealed either nucleotide deletion or insertion. In the other words, this indicated the difference between the nucleotides which caused distinction among these DNA segments. 


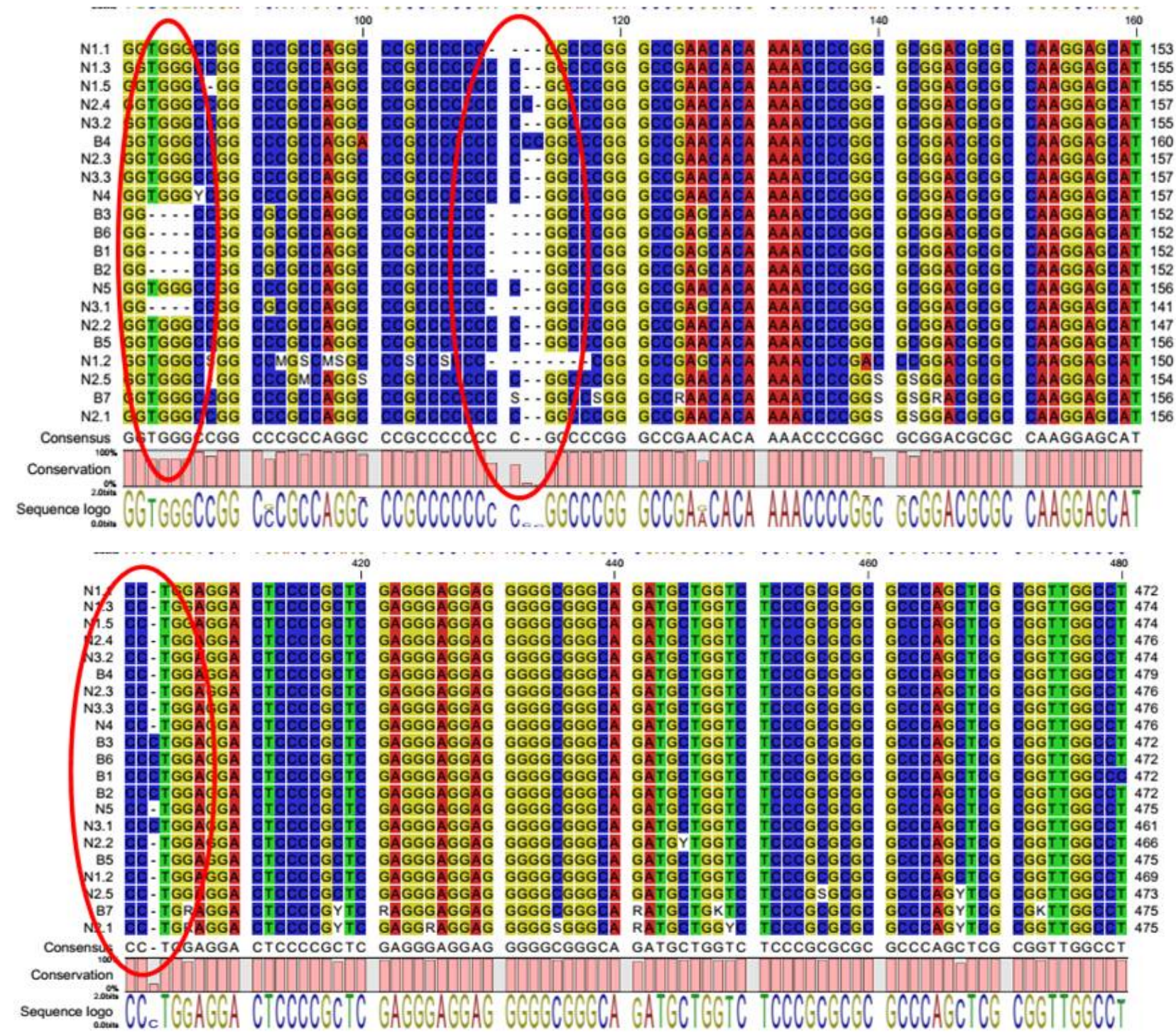

Figure 3. Aligned sequence of ITS regions of the Ochna samples.

We have made the comparison of each pair by BLAST tool to attain the ITS-rDNA region sequence correlation coefficient between the 21 Ochna models. The results of the sequence of identification matrix are shown in Fig. 4. It demonstrated that there was a high correlation between the sequences of 21 Ochna samples, of which the highest correlation coefficient was $100 \%$ and the lowest was $96.25 \%$, while the nearest genetic distance was 0.00 and the furthest was found by 0.02 .

\begin{tabular}{|c|c|c|c|c|c|c|c|c|c|c|c|c|c|c|c|c|c|c|c|c|c|c|}
\hline & & 1 & 2 & 3 & 4 & 5 & 6 & 7 & 8 & 9 & 10 & 11 & 12 & 13 & 14 & 15 & 16 & 17 & 18 & 19 & 20 & 21 \\
\hline N1.1 & 1 & & 0.00 & 0.00 & 0.01 & 0.00 & 0.01 & 0.00 & 0.00 & 0.00 & 0.01 & 0.01 & 0.01 & 0.01 & 0.01 & 0.01 & 0.01 & 0.01 & 0.01 & 0.01 & 0.01 & 0.01 \\
\hline $\mathrm{N} 1.3$ & 2 & 99.72 & & 0.00 & 0.01 & 0.00 & 0.01 & 0.00 & 0.00 & 0.00 & 0.01 & 0.01 & 0.01 & 0.01 & 0.01 & 0.01 & 0.01 & 0.01 & 0.01 & 0.01 & 0.01 & 0.01 \\
\hline N1.5 & 3 & 99.17 & 99.44 & & 0.01 & 0.00 & 0.01 & 0.00 & 0.00 & 0.00 & 0.02 & 0.02 & 0.02 & 0.01 & 0.01 & 0.01 & 0.01 & 0.01 & 0.01 & 0.01 & 0.02 & 0.01 \\
\hline $\mathrm{N} 2.4$ & 4 & 98.61 & 98.89 & \begin{tabular}{|l|l}
88.47 \\
\end{tabular} & & 0.01 & 0.00 & 0.01 & 0.01 & 0.01 & 0.01 & 0.01 & 0.01 & 0.01 & 0.00 & 0.01 & 0.01 & 0.01 & 0.01 & 0.00 & 0.01 & 0.01 \\
\hline N3.2 & 5 & 99.72 & 100.00 & 99.44 & 98.89 & & 0.01 & 0.00 & 0.00 & 0.00 & 0.01 & 0.01 & 0.01 & 0.01 & 0.01 & 0.01 & 0.01 & 0.01 & 0.01 & 0.01 & 0.01 & 0.01 \\
\hline$B 4$ & 6 & 98.34 & 98.61 & 98.48 & 99.17 & 98.61 & & 0.01 & 0.01 & 0.01 & 0.01 & 0.01 & 0.01 & 0.01 & 0.01 & 0.01 & 0.01 & 0.00 & 0.01 & 0.01 & 0.01 & 0.01 \\
\hline N2.3 & 7 & 99.30 & 99.58 & 99.31 & $\begin{array}{l}98.47 \\
\end{array}$ & 99.58 & \begin{tabular}{|l|l|}
98.75 \\
\end{tabular} & & 0.01 & 0.01 & 0.01 & 0.01 & 0.01 & 0.01 & 0.01 & 0.01 & 0.00 & 0.01 & 0.01 & 0.01 & 0.01 & 0.01 \\
\hline N3.3 & 8 & 99.17 & 99.44 & 99.17 & 98.47 & 99.44 & 98.48 & \begin{tabular}{|c|}
9.44 \\
\end{tabular} & & 0.00 & 0.02 & 0.02 & 0.02 & 0.02 & 0.01 & 0.01 & 0.01 & 0.01 & 0.01 & 0.01 & 0.02 & 0.01 \\
\hline N4 & 9 & $\begin{array}{l}99.17 \\
\end{array}$ & 99.44 & \begin{tabular}{|l|l|}
99.17 \\
\end{tabular} & 98.47 & \begin{tabular}{|l|l|}
994 \\
\end{tabular} & 98.48 & 99.44 & 100.00 & & 0.02 & 0.02 & 0.02 & 0.02 & 0.01 & 0.01 & 0.01 & 0.01 & 0.01 & 0.01 & 0.02 & 0.01 \\
\hline B3 & 10 & 97.50 & 9723 & 97.09 & 97.51 & 97.23 & 97.79 & 97.64 & 9709 & 97.09 & & 0.00 & 0.00 & 0.00 & 0.01 & 0.00 & 0.01 & 0.01 & 0.01 & 0.01 & 0.01 & 0.01 \\
\hline 86 & 11 & 97.50 & 9723 & \begin{tabular}{|c|}
97.09 \\
\end{tabular} & 97.51 & \begin{tabular}{|l|l|}
97.23 & \\
\end{tabular} & \begin{tabular}{|l|l}
97.79 \\
\end{tabular} & 97.64 & 97.09 & 97.09 & 100.00 & & 0.00 & 0.00 & 0.01 & 0.00 & 0.01 & 0.01 & 0.01 & 0.01 & 0.01 & 0.01 \\
\hline B1 & 12 & 97.50 & 97.23 & 97.09 & 97.51 & 97.23 & 97.79 & 97.64 & 97.09 & $\begin{array}{l}97.09 \\
\end{array}$ & 99.72 & 99.72 & & 0.00 & 0.01 & 0.00 & 0.01 & 0.01 & 0.01 & 0.01 & 0.01 & 0.01 \\
\hline B2 & 13 & 97.64 & 97.36 & 97.23 & 97.65 & 97.36 & 97.93 & 97.78 & 9723 & 9723 & 100.00 & 100.00 & 99.86 & & 0.01 & 0.00 & 0.01 & 0.01 & 0.01 & 0.01 & 0.01 & 0.01 \\
\hline N5 & 14 & 98.33 & 98.61 & 98.47 & 99.44 & 98.61 & 98.89 & 98.47 & 98.47 & 98.47 & 97.50 & 97.50 & 9750 & 97.64 & & 0.01 & 0.01 & 0.01 & 0.01 & 0.00 & 0.01 & 0.01 \\
\hline N3.1 & 15 & $\begin{array}{l}97.07 \\
\end{array}$ & 96.80 & 96.53 & 96.53 & 96.80 & 9627 & 96.94 & 96.81 & 9681 & $\begin{array}{l}98.46 \\
\end{array}$ & 98.46 & 98.18 & 98.46 & 96.80 & & 0.01 & 0.01 & 0.01 & 0.01 & 0.01 & 0.01 \\
\hline N2.2 & 16 & 97.77 & 98.05 & 97.77 & 97.78 & 98.05 & 97.51 & 98.19 & 98.05 & 98.05 & 96.39 & 96.39 & 9639 & 96.53 & 98.05 & 97.89 & & 0.00 & 0.01 & 0.01 & 0.01 & 0.01 \\
\hline B5 & 17 & 98.89 & 99.16 & \begin{tabular}{|l|l|}
98.75 \\
\end{tabular} & 99.30 & 99.16 & 99.03 & 99.03 & 98.61 & 98.61 & 97.92 & 97.92 & 97.92 & 98.06 & 99.03 & 96.81 & 98.05 & & 0.01 & 0.01 & 0.01 & 0.01 \\
\hline N1.2 & 18 & 98.32 & 98.05 & 97.64 & 98.05 & 98.05 & 97.78 & 97.92 & 97.50 & 97.50 & 97.50 & 97.50 & 97.50 & 97.64 & 97.77 & 96.38 & 96.80 & 98.61 & & 0.01 & 0.01 & 0.01 \\
\hline N2.5 & 19 & 98.19 & 98.47 & 98.33 & 99.30 & 98.47 & 98.48 & 98.06 & 98.06 & 98.06 & 97.09 & 97.09 & 97.09 & 97.23 & 9930 & 96.36 & 97.63 & 98.89 & 97.63 & & 0.01 & 0.01 \\
\hline 87 & 20 & 97.91 & 98.19 & 98.05 & 99.03 & 98,19 & 98.48 & 98.33 & 98.06 & 98.06 & 97.36 & 97.36 & 97.36 & 97.50 & 99.30 & 96.66 & 97.91 & 99.03 & 97.64 & 99.16 & & 0.01 \\
\hline N2.1 & 21 & 98.61 & 98.89 & 98.47 & 98.75 & 98.89 & 98.75 & 98.75 & 98.47 & 98.47 & 97.36 & 97.36 & 97.36 & 97.50 & 98.47 & 9625 & 9750 & 99.03 & 97.91 & 98.47 & 98.33 & \\
\hline
\end{tabular}

Figure 4. Correlation coefficient and genetic distance of ITS-rDNA of 21 Ochna samples. 
The phylogenetic trees based on ITS-rDNA of 21 Ochna samples

After identifying the region of nucleotide sequences of ITS-rDNA, the phylogenetic trees were generated as shown in Fig. 5. Based on the taxonomic tree, the regions of ITS-rDNA sequence of 21 samples species were divided into 2 main groups:

Group I: included ITS-rDNA region of the samples B1, B2, B3, B6 and N3.1.

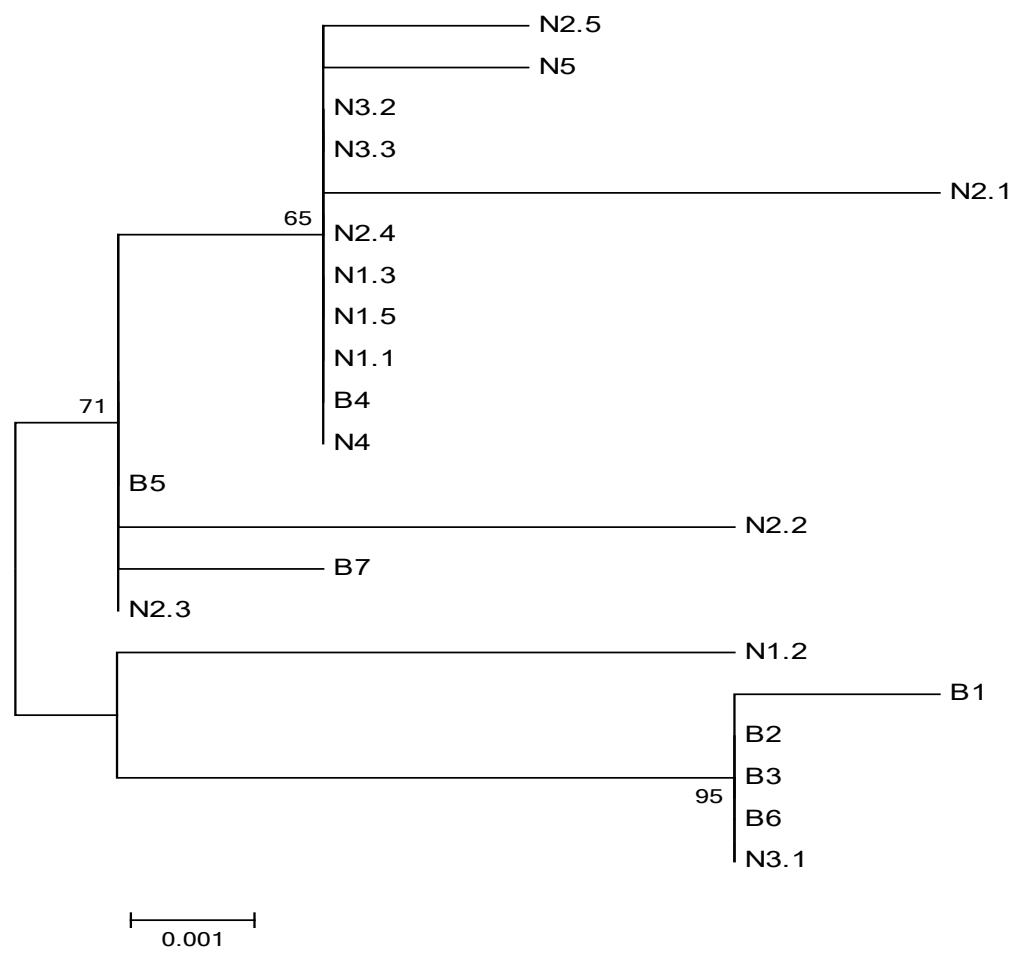

Figure 5. The phylogenetic trees of 21 Ochna samples.

The group II: consisted of the ITS-rDNA region sequence of the 16 samples: B4, B5, B7, N1.1, $\mathrm{N} 1.2, \mathrm{~N} 1.3, \mathrm{~N} 1.5, \mathrm{~N} 2.1, \mathrm{~N} 2.2, \mathrm{~N} 2.3, \mathrm{~N} 2.4, \mathrm{~N} 2.5, \mathrm{~N} 3.2, \mathrm{~N} 3.3, \mathrm{~N} 4$ and N5

Group II was divided into 2 subgroups: Subgroup I (P1): N1.2 and subgroup II (P2): B4, B5, B7, N1.1, N1.3, N1.5, N2.1, N2.2, N2.3, N2.4, N2.5, N3.2, N3.3, N4 and N5.

The ITS-rDNA region sequences of the 21 Ochna samples were identified. Amongst them, the size of ITS was ranged from $666 \mathrm{bp}$ to $721 \mathrm{bp}$; the percentage of $(\mathrm{G}+\mathrm{C})$ fluctuated from $64.6 \%$ to $65.7 \%$, and the average of ratio percentage was $65.3 \%$. Generally, 21 Ochna samples have attained similar size and $(\mathrm{G}+\mathrm{C})$ content ratio of the ITS region of many angiosperm species as published. In fact, ITS sequences were previously used to generate the first phylogeny of Rubus, which generally corresponded to their biogeography and polyploid, but not to their conventionally important morphological characters [19]. Our study has been congruent with the previous reports of Yuan et al. [20] and Trung et al. [14], who documented the relationship of Dendrobium species based on sequences characterization of the rDNA ITS region.

\section{Conclusions}

In this study, we have successfully identified the nucleotide sequences by use of ITS-rDNA and made the comparison among the samples in order to find out the evolutionary relationships among species or the genetic diversity of individual in the same species. It is the first report on identification of 21 Ochna samples by use of ITS1-5.8S-ITS2 gene sequences. The genetic correlations of the samples ranged from $96.25 \%$ to $100 \%$. Based on the difference in the ITS1-5.8SITS2 gene sequences, it has shown accurately determination of the 21 genetic resource of Ochna samples, of which, 5 samples include B1, B2, B3, B6 and N3.1 were divided into their own groups. 


\section{References}

[1] N.K.B. Robson, The author and typification of the genus Ochna, Taxon. 11(2) (1962) 48-52.

[2] A.B. Rendle, The classification of flowering plants, vol. 2, Cambridge University Press, Cambridge, 1952.

[3] N.D. Hoe, Explanation of ancient plant clusters, in: Yen Tu Environmental Forum, Association of Nature and Environment Protection (VACNE). 2011. Available: http://vacne.org.vn/tai-sao-yen-tu-4-giai-gia-manganese-carbonate-power-co-generation-yentu/25594.html. Retrieved: July 7, 2017.

[4] T. Hop, Bonsai and flower plants in Vietnam, Youth Publisher, Hanoi Vietnam, 1993. (in Vietnamese)

[5] A.K.R. Bandi et al., Phytochemical and biological studies of Ochna species, Chem. Biodiversity. 9(2) (2012) 251-271.

[6] G. Ma et al., Shoot organogenesis and somatic embryogeneisis from leaf and shoot explants of Ocha integerrima (Lour), Plant Cell Tissue Organ Cult. 104(2) (2011) 157-162.

[7] L. Kittisak et al., Flavonoids from Ochna integerrima, Phytochem. 56(4) (2001) 353-357.

[8] C.A. Williams, R. Grayer, Anthocyanins and other flavonoids, Nat. Prod. Reps. 21(4) (2004) 539-573.

[9] D.V. Dong, Golden age plant - precious germplasm with endanger. Report on investigation of Yen Tu - yellow flower plant, Fruit and Vegetable Research Institute, 2008.

[10] K. Ilic et al., The plant structure ontology, a unified vocabulary of anatomy and morphology of a flowering plant, Plant Physiol. 143(2) (2007) 587-599.

[11] The Angiosperm Phylogeny Group, An update of the Angiosperm Phylogeny Group classification for the orders and families of flowering plants: APG II, Bot. J. Linnean Soc. 141(4) (2003) 399-436.

[12] J.J. Hoyle, J.L. Doyle, A rapid DNA isolation procedure for small qualities of fresh leaf tissue, Phytochem. Bull. 19 (1987) 11-15.

[13] J. Sambrook, D.W. Russell, Molecular cloning, Third edition, Vol. 1, Cold Spring Harbor Laboratory Press, New York, 2001.

[14] K.H. Trung et al., Molecular phylogeny of the endangered Vietnamese Paphiopedilum species based on the internal transcribed spacer of the nuclear ribosomal DNA, Adv. Biol. Studies. 5(7) (2013) 337-346.

[15] P. Thao, H. Trang, The morphological characteristics of Yen Tu Ochna. Available: https://www.baomoi.com/dac-diem-nhan-dang-giong-mai-vang-yen-tu/c/22416504.epi, 2017. Retrieved: October 2, 2017. (in Vietnamese)

[16] T. Khoi, Yen Tu Ochna flower, 2014. Available: https://thuvienhoasen.org/a22043/hoa-maivang-yen-tu. Retrieved: October 2, 2017. (in Vietnamese)

[17] T.H. Dung et al., Application of DNA technology to classify and identify Dendrobium parishii and Dendrobium anosmum in Vietnam, J. Agri. Rural Dev. 18 (2012) 3-9.

[18] Y.T. Liu et al, Analysis of sequence diversity through internal transcribed spacers and simple sequence repeats to identify Dendrobium species, Gen. Mol. Res. 13(2) (2014) 2709-2717.

[19] L.A. Alice et al., Hybridization and gene flow between distantly related species of Rubus (Rosaceae): evidence from nuclear ribosomal DNA internal transcribed spacer region sequences, Systematic Botany. 26(4) (2001) 769-778.

[20] Q. Yuan, J.Y. Zhang, T. Liu, Phylogenetic relationship of China Dendrobium species based on the sequence of the internal transcribed spacer of ribosomal DNA, Biologia plantarum. 53(1) (2009) 155-158. 